\title{
Analysis of Distributive Public Policy-Making Model
}

\author{
Marlan Hutahaean \\ Department of Public Administration \\ nommensen HKBP university \\ Medan, Indonesia \\ marlanhutahaean1965@gmail.com
}

\begin{abstract}
This article talks about the model of distributive public policy-making like local regulation of poverty alleviation in Medan. The research question is how the policy actors such as the official of Medan and Local Parliament (DPRD) make of local regulationof poverty alleviation? Using qualitative methods with a policy analysis approach, it was found that, both the technocratic level, as well as the political level, the perceptions and elite models were dominant in the making of local regulation of poverty alleviation. Public participation as a policy target lacks a role in its formulation. Based on these findings, policy recommendation that should be done is the need for a combination of elite and participative or deliberative models in the making of local regulation.
\end{abstract}

Keywords- public policy, distributive policy, local regulation, poverty, elite and group model.

\section{INTRODUCTION}

This articleis to analyze the process of distributive public policy-making model which is taking the case of local regulations of poverty alleviation in Medan municipality. The focus of paperdiscusses how policymakers, both process of technocratic and political, formulating public policy in the form of local regulations of poverty alleviation. In the process of local regulations makingwhether the Local Government and the Local Parliament of Medan involve community participation

Lowi [1] dividepolicy typologies in to four categories: distributive, redistributive, regulatory, and constituent policies. Distributive policies aimed encouraging at community activities that are considered more desirable and beneficial to the wider community. The political behavior of policy actors is usually strongly influenced by the type of policy. In the type of distributive policy, usually the policy actors such as the government and legislators will be dominant [2]. This is because these policies provide budgetary implications such as poverty alleviation policy.

Why should be the case of the process of local regulations of poverty alleviation? There are at least three reasons to choose this local regulation. Firstly, it is a distributive or nonroutine policy. It means that, the local regulation made depends on its importance ornot every year formulated and used to overcome various it is problems in society. Secondly, this local regulation is that gives a direct one impact to the public, so it needs to be reviewed more deeply of how the role of public in the process of making it. The public as the policy target, logically should be involved in the process of making these local regulations. Third, in the study of public policy, there are various stages, namely agenda setting, policy formulation, policy adoption, policy implementation, policy monitoring and evaluation, and policy change. Researches on the policy implementation and evaluation has been done, otherwise researches on the public policy making is still very rare.

The research conducted by Wibawa [3], showed that the process of public polic-making: local cases in Indonesia is still focused in the executive or technocratic realm. The focus of his research is limited to how vertical and autonomous institutions formulate policies. The Research has not yet reached its discussion in the Local Parliament or the political level. Meanwhile,Hutahaean's research [4], did discuss policy making between municipality government and Local Parliament of Pematangsiantar on Regional Budget (APBD), but the focus is on the dynamics of divided or unified government, namely APBD which is annually discussed and determined through local regulation.

Lindblom [5] provides the best way to understand who and how to create policies. According to him, "one thing that must be understood is the characteristics of those who participate, what role they play, what authority and power they have, and how to agree and supervise each other." Furthermore He say that " participants, each playing a different role such as an ordinary citizens, head of interest groups, legislators, legislative leaders, party activists, party leaders, judges, public servants, technical experts, and business managers.

It means that the process of public policy-making is not a simple matter, because it involves many actors and is often accompanied by diverse interests. In terms of decisionmaking, usually the elite have competing interests. This competing interest will certainly affect the decision-making process [6]. The different competing interests are often influenced by values. There are at least five values that affect the actors that result in different interests. The values are (1) political values, (2) organizational values, (3) personal values, (4) policy values, and (5) ideological values [7].

\section{METHOD}

The case of the research is distributive public policymaking process in the form of localregulations of poverty alleviation in Medan municipality. This research wants to explore how the model of the process of local regulations of 
poverty alleviation making is done in Medan municipality. To reveal it, researchers used qualitative methods. Then, sampling technique used is purposive sampling, a sampling technique of data source with certain reason/consideration. Using this technique, some interviewees will be respondents such as heads of social and labor agencies, legal agencies of municipalities and Local Parliament members such as the head of Special Committee on Discussion on the Draft of Local Regulations of Poverty Alleviation. These informants are also called key informants. In addition, to enrich the information, some other sources such as community leaders, academics, NGOs, and journalists will also be respondents. They are often referred to as additional informants.

\section{RESULTS AND DISCUSSIONS}

Public policy-making in the form of local regulations of poverty alleviation is done through two process stages, namely technocratic process and political process. The technocratic process the process of local regulation which is done first by the concerns with government, in this case the municipality government of Medan. While the political process is the process of discussing the draft of local regulations in the Local Parliament for approval. Discussion of the results of this study, focused on the two policy-making process concerned.

At the technocratic level, the role of agency and bureaucrats is very important. They are the actors who determine whether the problem of poverty is really scheduled to be solved or just as lip service only. They can even manipulate data according to their interests [8]. They controlled the arena to decide whether public problems such as poverty are scheduled to be solve through a policy instrument or not.

The making of local legal drafting of poverty alleviation process begins with the problem of high poverty in Medan. Data in 2010 shows that the number of poor people in Medan municipality 341,587 inhabitants of about 2.5 million inhabitants. This figure is certainly very high and needs to get countermeasures. Regional Planning and Development Agency (Bappeda) of Medan municipality, after getting input from all Agencies, then take the initiative to do the handling through the making of Local Legal Drafting of Poverty Alleviation. The first step of Local Legal Drafting making is to form an Academic Drafting Team to conduct a scientific study on poverty in Medan. After the Academic Paper was completed in September 2011, the Local Legal Drafting on Poverty Alleviation was formulated in 2012.

Unfortunately, Local Legal Drafting which was formulated in 2012 has a weakness. First, the formulation of Local Legal Draftingdid not involve the poor who will become the target group. Second, the delivery of Local Legal Drafting to DPRD is too long, ie in January 2014 or about two years after local legal drafting be formulated. Thirdly, there are 6 (six) Local Legal Drafting which at the same time proposed to be discussed in DPRD which would make that the discussion not focus and not effective. The submission of 6 (six) Local Legal Drafting at the same time to be discussed in the Local Parliament gives the question that the municipality government is not serious in order for the Local Legal
Drafting of Poverty Alleviation to give good results when discussed in the DPRD.

Local Legal Drafting discussion on the political level can also not be expected to give maximum results. The acceptance of the discussion of 6 (six) Local Legal Drafting in the Plenary Session I on January 15, 2014 is certainly very unfortunate. Although in the Plenary Session II, on November 17, 2014, only 3 (three) Local Legal Drafting were discussed, namely Local Legal Drafting on B3 waste, Local Legal Drafting on Garbage and Local Legal Drafting on Poverty Alleviation, still the discussion of Local Legal Drafting will not give maximum result. Similarly with the establishment of the Special Committee, the discussion of Local Legal Drafting on Poverty Alleviation is not effective, because the concentration of the members of the council will be divided at the time of discussion in the Plenary Session. Besides thatthe discussion of Local Legal Drafting potential to be delayed. The proof of the delay in the discussion of Local Legal Drafting is that the approval of it on September 14, 2015 in the Plenary Session IV, or one year after the Plenary Session III on November 24, 2014. If calculated from the beginning of this Local Legal Drafting submission to the Local Parliament, the period of discussion Local Legal Drafting of Poverty Alleviationin the Local Parliament lasts for approximately one and a half years. Surely this is a relatively long time for a policy aimed at the poor.

At the time of discussion in theLocal Parliament, there was a correction made by the board members against the Local Legal Drafting on Poverty Alleviation at the time of discussion. The intended correction is first, in relation to the article that provides for the definition of the poor. In Local Legal Drafting proposed that "the poor are poor people who live in Medan municipality and have ID Card (KartuTandaPenduduk) and/or Family Card (KartuKeluarga) of Medan municipality" (Chapter I Article 1). Later, members of the board were corrected to, "the poor are the poor who live in the Medan municipality and have a ID Card and /or Family Card of Medan municipality and/or poor people who have been living for 6 months continuously in the Medan municipality." The correction is very basic and gives a sense of justice for those who have also long resided in Medan. Second, the correction to Article 10 paragraph (2) stating that "the financing as referred to in Article 10 paragraph (1) shall be adjusted to the resources capability of the Medan municipal government," replaced by a paragraph that reads, "to realize the implementation of poverty alleviation program, Medan municipal government shall set aside $10 \%$ of the LocallyGenerated Revenue (PendapatanAsli Daerah).

Nevertheless, there are also weaknesses shown by the Local Parliament during the discussion of the Local Legal Drafting of Poverty Alleviation. First, related to the insufficient percentage of poverty alleviation budget. For example, the realization of PAD in Medan in 2016 amounts to IDR 4.308 trillion from IDR 5.49 trillion target. Based on the amount of PAD, the city budget of Medan for Poverty Alleviation for 2017 amounted to IDR 430.8 Billion. With a total of 341,587 inhabitants in 2010, the average acceptable to the poor every month is IDR 105,100. - This amount is certainly very little and will be difficult to resolve poverty. 
Second, in the discussion of Local Legal Drafting of Poverty Alleviation has not involved public participation, especially the poor who become the target group. If any, those elected in public discussion are those from certain groups of people who are not representatives of the poor. This certainly has implications for the content of approved local regulations, due to the lack of information obtained about what the poor really need. Such information for example, why do they become poor? Is it due to their own behavior or because of structural obstacles in the form of certain access, such as access to information, access to jobs, or access to capital loans? This information will certainly be obtained if the poor are included in the discussion of the Local Legal Drafting of Poverty Alleviation in the Local Parliament.

\section{CONCLUSION}

Law Number 12 Year of 2011 on the Establishment of Laws and Regulations, actually has set the public role in policy making in the form of Law or Local Regulation. In Chapter XI regulated on community participation and in Article 96 paragraph (3) it is stipulated that those who are entitled to provide input, whether in writing or verbally are those, both individuals and groups of persons, who have an interest in the substance of the draft legislation. The problem is in practice, not done. Even if done, both the government and the Local Parliament elect those who are invited to provide input. If there is any input from the community, it is not necessarily that the input is used as material to improve the content of Local Legal Draftingof Poverty Alleviation. This condition indicates that the policy-making process is still or uses a perceptual model and an elite model.

The perceptual model indicates that the government and theLocal Parliament formulate the substance of Local Legal Draftingof Poverty Alleviation depend on their own perception. So, what is called poor, what are the parameters that state the poor, and how to deal with them depend on their perceptions. This is not much different from the elite model. In this model, the policy-making initiatives are dominated by elite desires such as government municipality and members of the Medan Local Parliament. The role of the community that is the largest group is often overlooked by the interests of the elite who are small groups. Public policy making that is heavily influenced by the behavior of actors should involve all actors such as individuals, groups, and organizations. The behavior of these actors is directed at solving various social and economic problems of society [9]. Unfortunately in the local regulations of poverty alleviation in Medan, only a handful of elite actors are involved, so the potential for solving poverty problems is very low. Thus, so thatLocal Legal Drafting to provide substantial benefits to the target group, besides the elite, then public participation, whether individuals, groups, or organizations, especially those directly concerned with the policies being made, should be further enhanced. Moreover, every actor involved in public policy making has bounded rationality [10].

\section{Acknowledgment}

The Author would liketo thank to the Public Administration Department, Faculty of Social and Political Sciences, HKBP Nommensen University that has funded this research. Thanks are also delivered to the Medan Municipal Government, members of Medan Local Parliament and other sources who have provided data and related information for this research.

\section{References}

[1] Lowi, T., "American Business, Public Policy, Case Studies, and Political Theory," World Politics vol. 16, pp. 677-715, 1964.

[2] Soha, M.E., "The Conditioning Effects of Policy Salience and Complexity on American Political Institutions," Policy Studies Journal, vol. 34, No. 2, pp. 223-243, 2006.

[3] Wibawa, S., "Public Policy Making Process: Local's Cases in Indonesia," Research Report, Faculty of Social and Political Sciences, UniversitasGadjahMada, Yogyakarta, 1992.

[4] Hutahaean, M., "'Transaction Fee" in the Dynamics of the Formation of either A Divided or Unified Government in Pematangsiantar City: A Case Study of Policy Making on Local Government Budgeting 20052010," Dissertation (Unpublished), Graduate Program, Faculty of Social and Political Sciences, UniversitasGadjahMada, Yogyakarta, 2013.

[5] Lindblom, C. E., The Policy Making Process, New Jersey: Prentice-Hall, Englewood Cliffs, 1980.

[6] Mazmanian, D.A. and Sabatier, P.A., "A Multivariate Model of Public Policy- Making, "American Journal of Political Science, vol. 24, No. 3, pp. 439-468, 1980.

[7] Wibawa, S. et.al., Public Policy Evaluation, Jakarta: Rajawali, 1994.

[8] Marshall, C., "Elites, Bureaucrats, Ostriches, and Pussycats: Managing Research in Policy Settings," Anthropology \& Education Quarterly, vol. 15, No. 3, pp. 235-251, 1984.

[9] Lynn, L.E. Jr., "The Behavioral Foundations of Public Policy-Making," The Journal of Business, vol. 59, No. 4, pp. S379-S384, 1986.

[10] Eisenhardt, K.M. and Zbaracki, M.J., "Strategic Decision Making," Strategic Management Journal, vol. 13, pp. 17-37, 1992. 